\title{
PENGARUH BOOKLET TERHADAP PENGETAHUAN, KONSUMSI ENERGI DAN PROTEIN ANAK SEKOLAH DASAR NEGERI 16 PONTIANAK TIMUR
}

\section{The Influence Booklet for Knowledge, Energy and Protein Consumption in Children of State Elementary School 16 East Pontianak}

\author{
Suaebah $^{1}$, Ayu Rafiony ${ }^{2}$ \\ Jurusan Gizi Poltekkes Kemenkes Pontianak \\ (suaebahgizi@gmail.com, 081345490855)
}

\begin{abstract}
ABSTRAK
Penelitian ini bertujuan untuk mengetahui pengaruh penyuluhan gizi berupa booklet terhadap pengetahuan, konsumsi energi dan protein pada anak Sekolah Dasar. Penelitian quasi eksperimen dengan rancangan pre-post test controlled grup. Kelompok 1 diberikan penyuluhan gizi dengan media booklet 1 kali sebulan, kelompok 2 diberikan 2 kali sebulan dan kelompok 3 diberikan 3 kali sebulan, dilaksanakan pada bulan Agustus-September 2017. Populasi penelitian adalah siswa kelas VA dan VB SDN 16 Pontianak Timur. Sampel sebanyak 24 orang masing-masing kelompok sebanyak 8 orang, secara random sampling. Analisis data menggunakan paired t-test dan test independet. Hasil penelitian menunjukkan pengetahuan kelompok 1 mengalami peningkatan yaitu 11,0\%, kelompok 2 meningkat $11,0 \%$ dan pada Kelompok 3 meningkat 10,5\%. Konsumsi energi meningkat pada kelompok 1 menjadi 1270,6 kalori. Pada kelompok 2 menurun menjadi 1310,7 kalori. Pada Kelompok 3 kali meningkat menjadi 1204,2 kalori. Konsumsi protein pada kelompok 1 kali meningkat menjadi 43,9 gr/hari. kelompok 2 kali meningkat menjadi 48,5 gr.hari, kelompok 3 kali meningkat menjadi 39,4 gr/hari. Kesimpulan, Skor rerata pengetahuan pada masing-masing kelompok meningkat setelah intervensi secara signifikan sebelum dan setelah intervensi. Demikian pula asupan energi dan protein, namun tidak ada perbedaan sebelum dan setelah intervensi. Penyuluhan mengenai sarapan sehat diperlukan agar asupan zat gizi siswa dapat terpenuhi.
\end{abstract}

Kata kunci : Booklet, Pengetahuan Gizi, Energi, protein

\section{ABSTRACT}

This study aims to find out information relating to books, knowledge, energy and protein in elementary school children. Quasi-experimental research with a controlled group pre-post test design. Group 1 was given nutritional counseling with media books 1 time a month, group 2 was given twice a month and group 3 was given 3 times a month, carried out in August-September 2017. The study population was VA and VB students in SDN 16 East Pontianak. A sample of 24 people each in 8 groups, by random sampling. Data analysis using paired t-test and independent test. The results showed that group 1 knowledge increased by 11.0\%, group 2 rose 11.0\% and in Group 3 it increased by 10.5\%. Energy consumption increased in group 1 to 1270.6 calories. In group 2 it decreased to 1310.7 calories. In the group 3 times increased to 1204.2 calories. Protein consumption in the group 1 time increased to $43.9 \mathrm{gr} /$ day. group 2 times increased to $48.5 \mathrm{gr}$. day, group 3 times increased to $39.4 \mathrm{gr} /$ day. The visual mean in each group increased after significantly significant before and after the intervention. Similarly, energy and protein intake, but there was no difference before and after the intervention. Counseling for a healthy breakfast is needed so that nutrient intake can be fulfilled.

Keywords : Booklet, Nutrition Knowledge, Energy, Protein 


\section{PENDAHULUAN}

Anak merupakan harapan masa depan. Karenanya perlu dipersiapkan agar kelak menjadi sumber daya manusia yang berkualitas, sehat, bermoral, dan berguna bagi masyarakat. Peningkatan derajat kesehatan masyarakat sangat diperlukan dalam mengisi pembangunan yang dilaksanakan oleh bangsa indonesia. Salah satu upaya peningkatan derajat kesehatan adalah perbaikan gizi masyarakat. Gizi yang seimbang dapat meningkatkan ketahanan tubuh, dapat meningkatkan kecerdasan dan menjadikan pertumbuhan yang normal ${ }^{(1)}$.

Dalam belajar diperlukan konsentrasi dalam perwujudan perhatian terpusat. Pemusatan perhatian tertuju pada suatu objek tertentu dengan mengabaikan masalah-masalah lain yang tidak diperlukan. Orang yang tidak dapat berkonsentrasi jelas tidak akan berhasil menyimpan atau menguasai bahan pelajaran. Oleh karena itu, setiap pelajar atau mahasiswa berusaha dengan keras agar mempunyai konsentrasi tinggi dalam belajar. Konsentrasi besar pengaruhnya terhadap belajar. Jika seseorang mengalami kesulitan dalam berkonsentrasi, jelas belajarnya akan sia-sia, karena hanya membuang tenaga, waktu, dan biaya saja $^{(2)}$.

Peningkatan konsentrasi belajar dapat dicapai dengan berbagai cara, salah satunya adalah makan pagi atau biasa disebut dengan sarapan. Makan pagi atau sarapan mempunyai peranan penting bagi anak sekolah usia 6-14 tahun, yaitu untuk pemenuhan gizi di pagi hari, dimana anak-anak berangkat kesekolah dan mempunyai aktivitas yang sangat padat di sekolah. Apabila anak-anak terbiasa sarapan pagi, maka akan berpengaruh terhadap kecerdasan otak, terutama daya ingat anak sehingga dapat mendukung prestasi belajar anak ke arah yang lebih baik. Sarapan pagi merupakan pasokan energi untuk otak yang paling baik agar dapat berkonsentrasi di sekolah. Ketika bangun pagi, gula darah dalam tubuh kita rendah karena semalaman tidak makan. Tanpa sarapan yang cukup, otak akan sulit berkonsentrasi di sekolah.

Sarapan adalah makan di waktu pagi sebelum tubuh mulai melakukan aktivitas, biasanya dilakukan sebelum jam 9 pagi. Sarapan pagi secara teratur dapat menyediakan energi yang cukup dalam beraktivitas sehingga prestasi belajar dapat dipertahankan. Sarapan pagi merupakan hal yang seringkali disepelekan banyak orang, padahal dengan sarapan pagi tubuh akan memperoleh nutrisi yang dibutuhkan setelah berpuasa kurang lebih 8 jam di malam hari.

Sarapan memberikan kontribusi penting karena menyumbang sekitar $25 \%$ dari total asupan gizi dalam sehari. Jika kecukupan energi adalah $2000 \mathrm{Kcal}$ dan protein $50 \mathrm{~g}$, maka sarapan menyumbang $500 \mathrm{Kcal}$ energi dan $12,5 \mathrm{~g}$ protein. Hal ini menyebabkan seseorang yang tidak sarapan sulit untuk memenuhi kebutuhan gizinya. Energi dari sarapan dikatakan adekuat jika setidaknya menyumbang minimal $20 \%$ dari total asupan sehari. Menurut Soedibyo dan Gunawan 
konsumsi sarapan berenergi tinggi (>25\% RDA) dapat memberikan asupan vitamin dan mineral harian yang lebih tinggi dibandingkan sarapan berenergi sedang (15-25\%RDA) dan berenergi rendah $(<15 \%)^{(3)}$.

Berdasarkan penelitian yang dilakukan Sunarti setiap peningkatan $1 \mathrm{kcal}$ asupan energi dari sarapan memberikan kontribusi peningkatan skor konsentrasi sebesar 0,34 sedangkan $1 \mathrm{~g}$ protein dapat meningkatkan skor konsentrasi belajar sebesar 0,29(4). Penelitian yang dilakukan Wyon dari hasil recall sarapan anak-anak yang mengonsumsi sarapan dengan energi tinggi secara signifikan lebih sedikit merasa lapar dan memiliki integritas yang lebih baik di sekolah ${ }^{(5)}$

Tujuan penelitian ini untuk untuk mengetahui pengaruh penyuluhan gizi berupa booklet terhadap pengetahuan, konsumsi energi dan protein pada anak Sekolah Dasar Negeri 16 Pontianak Timur.

\section{METODE PENELITIAN}

Jenis penelitian ini merupakan penelitian quasi eksperimen dengan rancangan pre-post test controlled grup pada anak SD sebagai subjek penelitian. Pada kelompok 1 diberikan penyuluhan gizi dengan media booklet 1 kali sebulan,kelompok 2 diberikan penyuluhan gizi dengan media booklet 2 kali sebulan dan kelompok 3 diberikan penyuluhan gizi dengan media booklet 3 kali dalam sebulan. Penelitian dilaksanakan pada bulan Agustus s/d September 2018 di SDN Pontianak Timur.
Populasi penelitian adalah adalah siswa kelas VA dan VB di SDN 16 Pontianak Timur. Jumlah sampel sebanyak 24 orang masing-masing kelompok sebanyak 8 orang, pengambilan sampel secara random sampling. Analisis data menggunakan analisis pairet $t$ test dan test independet.

\section{HASIL}

Berdasarkan hasil penelitian bahwa umur responden terbanyak pada kelompok umur 10 tahun yaitu $44 \%$ dan jenis kelamin terbesar laki-laki sebesar 56\%. Selengkapnya dapat dilihat pada tabel 1 .

Tabel 1. Karakteristik Responden berdasarkan umur dan jenis kelamin di Sekolah Dasar Negeri 16 Pontianak Timur

\begin{tabular}{ccc}
\hline \multirow{2}{*}{ Variabel } & \multicolumn{2}{c}{ Jumlah } \\
\cline { 2 - 3 } & n & $\%$ \\
\hline Umur (Tahun) & 2 & 8,0 \\
9 & 11 & 44,0 \\
10 & 5 & 20,0 \\
11 & 6 & 24,0 \\
12 & 1 & 4,0 \\
13 & & \\
Jenis Kelamin & 14 & 56,0 \\
Laki-laki & 11 & 44,0 \\
Perempuan &
\end{tabular}

Sumber : Data Primer, 2018

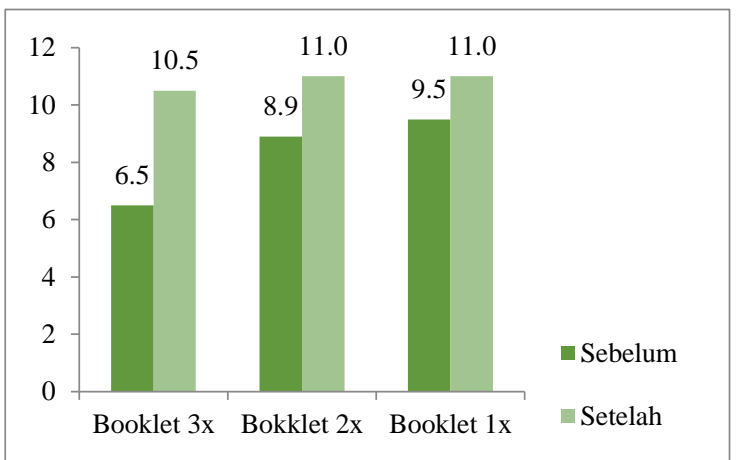

Gambar 1. Perbedaan Rerata Pengetahuan Sebelum dan Setelah Booklet Pada Ketiga Kelompok Intervensi di Sekolah Dasar Negeri 16 Pontianak Timur 
Pada gambar 1 dapat diketahui bahwa, kelompok yang diberikan penyuluhan booklet sebanyak 3 kali pengetahuannya meningkat yaitu $10,5 \%$, sedangkan pada kelompok yang diberikan booklet sebanyak 2 kali pengetahuannya juga meningkat yaitu $11,0 \%$ dana pada kelompom yang diberikan booklet 1 kali pengetahuannya juga mengalami peningkatan yaitu $11,0 \%$. Berdasarkan hasil analisis uji paired t-test $(\mathrm{p}<0,05)$ ada pengaruh penyuluhan dengan media booklet yang diberikan $3 x$ sebulan terhadap pengetahuan pada anak sekolah dasar.

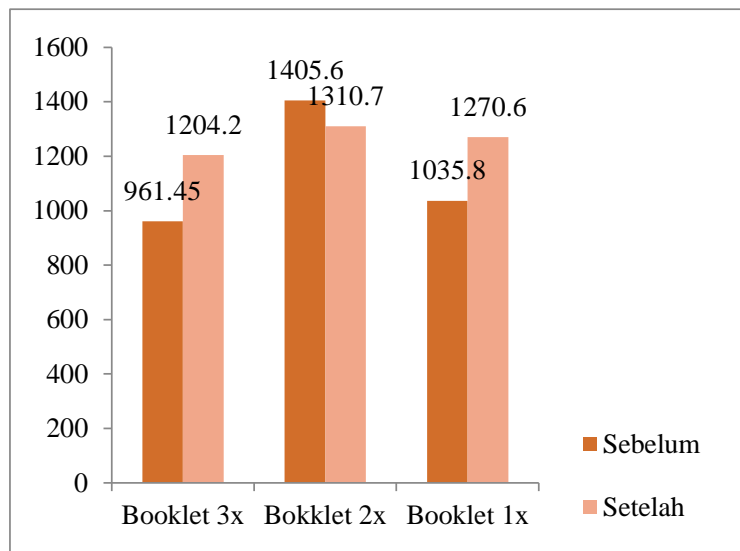

Gambar 2. Perbedaan Rerata Konsumsi Energi Sebelum dan Setelah Booklet Pada Ketiga Kelompok Intervensi di Sekolah Dasar Negeri 16 Pontianak Timur

Pada gambar 2 dapat diketahui bahwa konsumsi energi pada kelompok yang diberikan booklet sebanyak 3 kali terjadi peningkatan konsumsi energi setelah intervensi yaitu 1204,2 kalori, sedangkan pada kelompok yang diberikan booklet sebanyak 2 kali konsumsi energi terjadi penurunan setelah intervensi yaitu 1310,7 kalori, pada kelompok yang diberikan booklet sebanyak 1 kali konsumsi energi terjadi peningkatan setelah intervensi yaitu 1270,6 kalori. Namun berdasarkan hasil uji paired t-test $(\mathrm{p}>0,05)$ bahwa tidak ada pengaruh penyuluhan terhadap konsumsi energi pada anak SDN 16 Pontianak Timur.

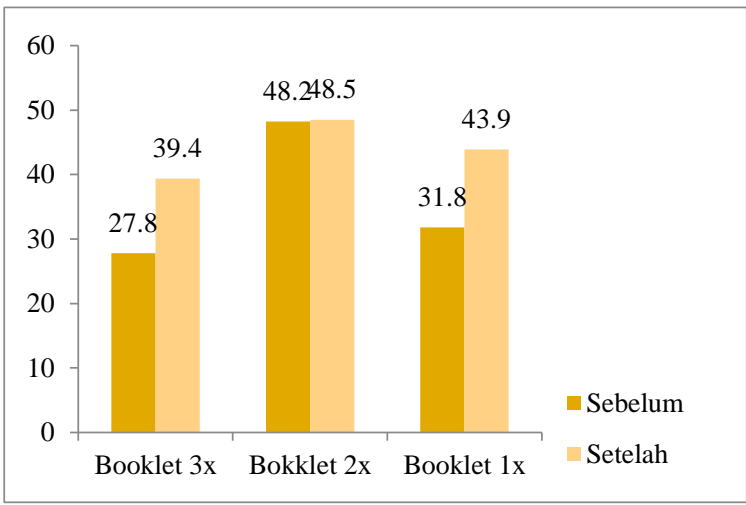

Gambar 3. Perbedaan Rerata Konsumsi Protein Sebelum dan Setelah Booklet Pada Ketiga Kelompok Intervensi di Sekolah Dasar Negeri 16 Pontianak Timur

Pada gambar 3 dapat diketahui bahwa konsumsi protein pada kelompok yang diberikan booklet sebanyak 3 kali terjadi peningkatan konsumsi protein setelah intervensi yaitu 39,4 gr/hari, sedangkan pada kelompok yang diberikan booklet sebanyak 2 kali konsumsi protein terjadi peningkatan walaupun sedikit setelah intervensi yaitu 48,5 gr.hari, pada kelompok yang diberikan booklet sebanyak 1 kali konsumsi protein terjadi peningkatan setelah intervensi yaitu 43,9 gr/hari. Dibuktikan dengan hasil uji paired $t$ test $(\mathrm{p}<0,05)$ bahwa ada pengaruh penyuluhan terhadap konsumsi protein pada anak SDN 16 Pontianak Timur. 


\section{PEMBAHASAN}

Perbedaan Pengetahuan Sebelum Dan Setelah Penyuluhan Dengan Media Booklet Pada Anak SDN 16 Pontianak Timur

Pengetahuan merupakan hasil penginderaan manusia, atau hasil mencari tahu seseorang ter-hadap objek melalui indera yang dimilikinya (mata, hidung, telinga, dan sebagainya). Hasil penelitian ini menunjukkan bahwa ada tiga kelompok perlakuan dengan masa pemberian penyuluhan yang berbeda terdapat pengaruh penyuluhan terhadap tingkat kengetahuan sarapan sehat pada anak SDN 16 Pontianak, terutama pada kelompok yang diberikan penyuluhan dengan media booklet 3 kali dalam sebulan.

Hasil penelitian ini sejalan dengan beberapa jenis penelitian terdahulu yang dilakukan pada beberapa tempat namun media yang berbeda, seperti penelitian yang dilakukan oleh Qazvin tentang efek pendidikan kesehatan dalam mengubah perilaku gizi dan pengetahuan pada siswa sekolah dasar, menunjukkan bahwa pengetahuan anak sebelum diberikan pendidikan sebesar 22.79 \pm 5.4 dan meningkat menjadi $51.46 \pm 4.75$ setelah dilakukan pelatihan pendidikan ${ }^{(6)}$.

Penelitian lain yang dilakukan oleh Shariff et al. tentang intervensi pendidikan gizi dalam upaya pe-ningkatan pengetahuan, sikap, dan praktek gizi terhadap 335 anak sekolah dasar di Malaysia menunjukkan hasil terdapat peningkatan skor pengetahuan, sikap, dan praktek setelah diberikan intervensi ${ }^{(7)}$. Rerata perubahan pengetahuan sebesar 2.71 $(\mathrm{p}<0.001)$, rerata perubahan sikap sebesar 1.40 $(\mathrm{p}<0.001)$, dan rerata perubahan praktek sebesar $0.87 \quad(\mathrm{p}<0.001)$. Hasil uji beda menunjukkan terda-pat perbedaan pengetahuan, sikap, dan praktek yang signifikan antara grup kontrol dan grup intervensi setelah diberikan intervensi.

Hasil penelitian Dunn menunjukkan bahwa 91.8\% subjek mengakui jika kartu bergambar "Color Me Healthy" meningkatkan pengetahuan anak-anak tentang gerakan. Selain itu, 93.0\% subjek menunjukkan bahwa menggunakan kartu begambar "Color $\mathrm{Me}$ Healthy" meningkatkan pengetahuan anakanak tentang makan yang sehat ${ }^{(8)}$.

Penelitian yang dilakukan oleh Dunts mengenai efek dari media puppet terhadap pengetahuan dan sikap anak sekolah dasar penyandang cacat dengan jumlah subjek sebanyak 966 dalam 40 kelas di enam sekolah dasar di daerah utara dan selatan Amerika Serikat menunjukkan bahwa terdapat peningkatan sikap yang lebih positif skor sikap pada kelompok intervensi $7.21 \pm 1.55$, sedangkan pada ke-lompok kontrol $6.53 \pm 1.85$ $(\mathrm{p}<0.0001)^{(9)}$.

\section{Perbedaan Konsumsi Energi Dan Protein Sebelum Dan Setelah Penyuluhan Dengan Media Booklet Pada Anak SDN 16 Pontianak Timur}

Membiasakan anak usia 8-11 tahun untuk sarapan akan mempengaruhi kemampuan anak dalam memecahkan masalah dan konsentrasi membaik, sikap, dan prestasi lebih baik. Melewatkan sarapan akan 
menyebabkan tubuh kekurangan glukosa, sehingga dapat menyebabkan tubuh lemah dan kurang konsentrasi karena tidak tersedia suplai energi.

Hasil penelitian ini mengatakan bahwa, konsumsi energi dan protein pada kelompok yang diberikan penyuluhan dengan media booklet sebanyak 2-3 kali dalam sebulan terjadi peningkatan konsumsi baik energi maupun protein. Rerata peningkatan asupan energi pada kelompok penyuluhan dengan media booklet selama 3 kali adalah 1204,2 kalori/hari, begitu juga konsumsi protein terjadi peningkatan yaitu 39,4 gr hari, namun berdasarkan hasil uji paired t-test tidak ada perbedaan yang signifikan sebelum dan setelah intervensi.

Penelitian ini sejalan dengan penelitian yang dilakukan oleh Kayapinar tentang "Body Mass Index, Dietary Habits, and Nutrition Knowledge among Primary School" menunjukkan hasil bahwa sebesar 32\% dari 200 siswa melewatkan sarapan mereka ${ }^{(10)}$. Hasil penelitian di Amerika juga menunjukkan 22\% anak sekolah berangkat sekolah tanpa $\operatorname{sarapan}^{(11)}$. Melewatkan sarapan akan menyebabkan cadangan energi tubuh menjadi habis setelah semalaman. Jarak sekitar dua belas jam antara makan malam dan sarapan akan menyebabkan penurunan kadar glukosa darah, sehingga menyebabkan kekurangan glukosa. Jika hal ini terjadi, dapat menyebabkan gangguan dalam fungsi otak ${ }^{(12)}$. Hasil studi di Indonesia, dimana sekitar 20 hingga 40\% anakanak Indonesia tidak terbiasa untuk sarapan ${ }^{(13)}$.
Sebelum dilakukan intervensi berupa penyuluhan dengan media booklet jenis sarapan anak sekolah tidak bervariasi, hanya berupa nasi kuning, bubur dan nasi goreng. Namun setelah diberikan penyuluhan menu sarapan anak sekolah telah bervariasi dan berwarna-warni yang memenuhi gizi seimbang, misalnya: nasi dengan telur + oseng-oseng sayuran, nasi dengan ikan goreng, tempe bacem + sayuran dan menu yang lain adalah nasi dengan omelet + sambal tempe + kerupuk.

\section{KESIMPULAN DAN SARAN}

Skor rerata pengetahuan terjadi peningkatan setelah intervensi pada ke 3 kelompok perlakuan, dan berdasarkan hasil uji paired t-test ada perbedaan yang signifikan sebelum dan setelah intervensi pada kelompok yang diberikan peyuluhan dengan media booklet sebanyak 3 kali. Skor rerata konsumsi energi terjadi peningkatan setelah intervensi pada ke 3 kelompok perlakuan, namun tidak ada perbedaan sebelum dan setelah intervensi. Skor rerata konsumsi protein terjadi peningkatan setelah intervensi pada ke 3 kelompok, namun tidak ada perbedaan sebelum dan setelah intervensi. Penyuluhan gizi khususnya mengenai sarapan sehat harus dilaksanakan secara berkelanjutan oleh semua pihak yaitu anak-anak, ibu, guru, dan tokoh masyarakat. Hal ini diperlukan agar kebiasaan sarapan selalu diterapkan sehingga asupan zat gizi dapat terpenuhi. Pada penelitian selanjutnya disarankan untuk menggunakan 
alat bantu yang lebih cocok untuk anak SD seperti kartu bergambar atau kampanye yang muda diterima dan dipahami dengan memperhatikan isi materi yang akan disampaikan kepada anak -anak sekolah dasar sehingga anak-anak dapat menerapkan kebiasaan sarapan dengan baik, serta lebih banyak menggunakan jumlah sampel sehingga analisis lebih muda dan bisa memberikan hasil lebih baik.

\section{UCAPAN TERIMA KASIH}

Kepada Ketua Jurusan Gizi dan Direktur Poltekkes Kemenkes Pontianak atas bantuan publikasi artikel ini serta kepada responden penelitian.

\section{DAFTAR PUSTAKA}

1. Lasidi.OD, Umboh.A Ismanto.Y, Hubungan Status Gizi Dan Kualitas Sarapan Pagi Dengan Prestasi Belajar Siswa Kelas IV dan V di SD Negeri 21 Manado, e-Journal Keperawatan (eKp) Volume 6 Nomor 1, Mei 2018

2. Slameto. 2013. Belajar dan faktor-faktor yang mempengaruhinya. Jakarta: PT Rineka Cipta

3. Soedibyo.S, Gunawan.H, Kebiasaan Sarapan di Kalangan Anak Usia Sekolah Dasar di Poliklinik Umum Departemen Ilmu Kesehatan Anak FKUI-RSCM, Sari Pediatri, Vol 11 No 1 Juni 2009.

4. Sunarti, E., Julia, M., Adiyanti, M. G. 2006. Pengaruh Pembeian Makan Tambahan Terhadap Presfasi Belajar Siswa Sekdah Dasar. Berita Kedokteran Masyarakat. Vol 22, No. 2, Hal55-60

5. Wyon DP, Abrahamsson L, Järtelius M, Fletcher RJ., An experimental study of the effects of energy intake at breakfast on the test performance of 10-year-old children in school. Int $\mathrm{J}$ Food Sci Nutr. 1997 Jan;48(1):5-12.

6. Motamedrezaei O, Mitra M, Mohammad RM, \& Maryam K. 2013. The effect of nutrition and food hygiene education on the knowledge of female elementary school teachers in city of Ferdows. Journal of Education and Health Promotion.

7. Mohd Shariff Z, Bukhari SS, Othman N, Hashim N, Ismail $M$, et al. (2008) Nutrition education intervention improves nutrition knowledge, attitude and practices of primary school children: A pilot study. Int Electron J Health Educ 11:119-32

8. Dunn C et al. 2006. Design and implementation of a nutrition and physical activity curriculum for child care settings. Public Health Research, Practice, and Policy. Prev Chronic Dis, 3(2), A58.

9. Dunts CJ. 2012. Effects of puppetry on elementary students' knowledge of and attitudes toward individuals with disabilities. Orelena Hawks Puckett Institute, United States. International Electronic Journal of Elementary Education, 4(3), 451-457.

10. Kayapinar FC. 2011. Body mass index, dietary ha-bits, and nutrition knowledge among primary school students. Egitim Arastirmalari-Eurasian Journal of Educational Research, 11(42), 135-152.

11. Mahoney CR, Taylor HA, Kanarek RB, \& Samuel P. 2005. Effect of breakfast composition on cognitive processes in elementary school children. Journal of Physiology and Behavior, 85, 635-645.

12. Latifah M. AL-Oboudi, Impact of Breakfast Eating Pattern on Nutritional Status, Glucose Level, Iron Status in Blood and Test Grades among Upper Primary School Girls in Riyadh City, Saudi Arabia, Pakistan Journal of Nutrition, Volume: 9:2 halaman 106-111

13. Hardinsyah. 2012. Keynote speech for healthy breakfast symposium. Pergizi Pangan Indonesia. http://pergizi.org. 